HTTP://DX.DOI.ORG/10.12775/SZHF.2016.047

\title{
Rządy filozofów Idea senatu w De optimo senatore Wawrzyńca Goślickiego
}

Wawrzyńca Goślickiego należy uznać za filozofa w największym stopniu niedocenionego spośród wszystkich polskich myślicieli staropolskich. Jego dzieło $O$ senatorze doskonałym ${ }^{1}$ zostało przetłumaczone na język polski dopiero 432 lata po wydaniu tekstu po łacinie. Co prawda fragmentów z jego traktatu nie zabrakło w tomie 700 lat myśli polskiej, poświęconemu wiekowi XVI, niemniej nie pozwalały one na chociażby pobieżne zapoznanie się z jego myślą. Jest to warte odnotowania, ponieważ wcześniejsze okazało się tłumaczenie na język angielski z $1578^{2}$. Przekład angielski zaowocował tym, że Goślicki był znany amerykańskim studentom na długo przed tym, jak ukazał się polski przekład³.

${ }^{1}$ W. Goślicki, O senatorze doskonałym, Kraków 2000.

${ }^{2}$ A. Stępkowski, Obecność „De optimo senatore” za granica, [w:] O senatorze doskonałym studia. Prace upamiętniające twórczość Wawrzyńca Goślickiego, red. A. Stępkowski, Warszawa 2009.

3 „Okazało się, że być może właśnie to genius loci Charlottesville miało szczególne znaczenie. Amerykanie są przekonani - i mają po temu pewne podstawy - że główne dzieło Goślickiego „De optimo senatore” w tłumaczeniu na angielski (a były przecież przynajmniej trzy wyda- 
Choć od powtórnego wydania dzieła Goślickiego minęło już piętnaście lat, jego myśl ciągle jest nieznana szerszemu gronu badaczy, a liczba prac poświęcona jego dorobkowi cały czas może być określona jako znikoma ${ }^{4} \mathrm{w}$ stosunku do filozoficznego potencjału tkwiącego w dziele Goślickiego. W zbiorowej publikacji poświęconej twórczości staropolskiego myśliciela można bowiem przeczytać teksty niezwykle interesujące, analizujące De optimo senatore z punktu widzenia filologii polskiej, historii, politologii czy też prawa, cały czas jednak brakuje monografii, która wypunktowałaby filozoficzne aspekty myśli Goślickiego. Traktat Goślickiego zasługuje na szczególną uwagę ze względu na niezwykłą wyjątkowość jego myśli na tle myśli staropolskiej. Jako jedyny w tak dogłębny sposób dokonał refleksji nad senatem Rzeczpospolitej i jego miejscu w ustroju. Różnił się w tym znacząco od współczesnych mu autorów, w których refleksja nad senatem zajmowała miejsce poboczne i nie była przedmiotem szczegółowych refleksji. Propozycja Goślickiego była wyjątkowa właśnie ze względu na postulowaną wizję senatora i ze względu na wzorzec, do którego się odwoływał. Co jeszcze istotniejsze, odsyłał w nim nie do święcącego wtedy triumfy Arystotelesa, ale do cieszącego się znacznie mniejszą popularnością Platona, próbując dostosować idee z Państwa do realiów Rzeczpospolitej.

W niniejszym artykule jego koncepcje filozoficzne zostaną zestawione z obecnymi w Rzeczpospolitej przekonaniami o roli senatu i wzorcami senatora. Wizję senatu przedstawioną przez Goślickiego zaprezentuję na tle poglądów głoszonych przez trzech ważnych autorów polskiego modelu republikanizmu: nauczyciela Goślickiego, Jakuba Górskiego oraz Stanisława

nia angielskie) było znane większości twórców konstytucji Stanów Zjednoczonych. Jeżeli zaś mowa o Charlottesville, Uniwersytet Wirginii został założony przez Tomasza Jeffersona i jego duch tam wydaje się wciąż żywy. Nie można zatem nie dostrzegać głębokiego przekonania o istnieniu wpływu Wawrzyńca Goślickiego obok tak wybitnych myślicieli jak Locke i Monteskiusz, na idee konstytucjonalizmu amerykańskiego. Co do znajomości twórczości polskiego biskupa w Stanach Zjednoczonych, do powstania przekonania o jego wpływie na Ojców konstytucji USA przyczynili się tu nie tylko Polonusi i Polacy. Zarówno ze względów merytorycznych i - jak to często bywa - ze względu na zbieg okoliczności, twórczość Goślickiego żyła w świecie anglosaskim i żyje do tej pory w Stanach Zjednoczonych.” Fragment wypowiedzi prof. Izdebskiego, cyt. za: A. Stępkowski, Wprowadzenie, [w:] O senatorze doskonałym studia, dz. cyt., s. 4-5.

${ }^{4}$ Niewątpliwe olbrzymie zasługi na rzecz przybliżenia dorobku Goślickiego ma profesor Aleksander Stępkowski, pod którego redakcją ukazał się jedyny jak dotąd zbiór artykułów poświęconych twórczości Goślickiego. 
Orzechowskiego i Andrzeja Frycza-Modrzewskiego - dwóch najpopularniejszych spośród myślicieli wieku XVI.

\section{Rys biograficzny}

Niemożliwe jest zaprezentowanie myśli Goślickiego bez chociażby szkicowego przedstawienia jego życia. W przypadku polskiej myśli politycznej kontekst kulturalny, edukacja oraz funkcja pełniona w państwie odgrywają niezwykle istotną rolę.

Wawrzyniec Goślicki urodził się między rokiem 1527 a $1536^{5}$ w rodzinie szlachty mazowieckiej. Wiadomo, że rodzina wsławiła się nie tylko licznymi wojskowymi ${ }^{6}$, ale także przedstawicielami kleru. Jego stryjem, a zarazem dobroczyńcą był kanonik płocki, Marcin. Studia na Uniwersytecie Jagiellońskim przyszły biskup Goślicki rozpoczął na przełomie 1556 i 1557 roku. Właśnie te studia, pod okiem największego spośród polskich znawców Cycerona (Jakuba Górskiego), ukształtowały jego myśl filozoficzną. Mistrz autora De optimo senatore najwyraźniej docenił jego umiejętności, jego dwa epigramy zostały bowiem dołączone do polemiki Górskiego z Herbstem. Dziś niemożliwe jest prześledzenie, jakie były okoliczności spotkania Goślickiego z największym orędownikiem demokracji szlacheckiej, Stanisławem Orzechowskim, wiadomo jednak, że obaj znali się dobrze i blisko współpracowali. Praca poświęcona relacji między autorem De optimo senatore a największym wyrazicielem koncepcji republikanizmu szlacheckiego cały czas jeszcze nie powstała. Można jednak śmiało powiedzieć, że obydwaj wymienieni myśliciele głosili poglądy, dla których raczej nie dałoby się znaleźć żadnego iunctim.

Goślicki, podobnie jak wielu jego kolegów ${ }^{7}$, kontynuował studia na uniwersytecie w Padwie, gdzie Polacy stanowili niemałą reprezentację studentów. Tam właśnie, pod okiem Karola Sygoniusza, pogłębiał swą edukację.

\footnotetext{
${ }^{5}$ Wśród badaczy panuje duża rozbieżność w tym względzie. Fragment poświęcony biografii Goślickiego oparłem na notatce D. Maniewskiej z Polskiego słownika bibliograficznego, t. 9, Kraków 1959 oraz artykule A. Stępkowski, Wawrzyniec Goślicki przyczynek do biografii "O senatorze doskonatym”, [w:] O senatorze doskonalym studia, dz. cyt.

${ }^{6}$ Rodzina Goślickiego wsławiła się szczególnie w walkach z zakonem krzyżackim. Jego dziad, Mikołaj z Chalina, był nawet dowódcą Zygmunta Starego w zwycięskiej batalii pod Proboszowicami.

${ }^{7}$ H. Barcz, Polacy na studiach w Rzymie w epoce Odrodzenia 1440-1600, Kraków 1938.
} 
Kiedy ten na skutek konfliktu udał się do Bolonii, Wawrzyniec Goślicki pojechał za nimi w 1567 roku uzyskał tytuł doktora. Równocześnie, co nie było niczym niezwykłym w tamtym czasie, odbył podróż po Półwyspie Apenińskim, podczas której odwiedził zarówno wieczne miasto, gdzie nawiązał kontakt z tamtejszymi elitami intelektualnymi, jak i Neapol. Swoją naukową wędrówkę zakończył w 1568 roku w Wenecji, gdzie w drukarni Jordana Zilettiego wydał swoje najważniejsze dzieło De optimo senatore, rozprawę będącą owocem jego namysłu nad filozofią Platona i Cycerona.

Powrót do kraju oznaczał dla niego początek kariery w kancelarii królewskiej. W 1570 roku jako wysłannik z ramienia króla wszedł w skład komisji Karnowskiego i udał się na pertraktacje do Gdańska. Kolejną jego misją była podróż dyplomatyczna na Węgry.

Choć w czasie drugiego bezkrólewia należał do stronnictwa cesarskiego, to jednak po dojściu do władzy Stefana Batorego utrzymał swoje stanowisko. $\mathrm{Na}$ jego dalszą karierę składały się przede wszystkim misje dyplomatyczne do Gdańska, Siedmiogrodu i na Węgry. W tym czasie, pomimo różnicy zdań i czasowych konfliktów, uchodził za zwolennika kanclerza Zamojskiego.

Po śmierci Batorego czynnie zaangażował się w wybór Zygmunta III Wazy, opracowując pacta conventa dla tego władcy i witając go mową Witanie rady stanów koronnych polskich do króla jegomości Zygmunta III. W początkowym okresie jego panowania, kiedy narastały różnice między królem a kanclerzem Zamojskim, pełnił funkcję mediatora. Podobnie jak w przypadku koncepcji politycznych zawartych $\mathrm{w}$ jego pismach, również w swoich politycznych działaniach skłaniał się do wstrzemięźliwości, czego wyrazem był między innymi gorący sprzeciw wobec włączenia się w pierwszą dimitriadę.

Ostatnie lata jego życia przypadły na burzliwy czas rokoszu zebrzydowskiego. Nie brał w nim jednak czynnego udziału i nie opowiedział się po żadnej ze stron konfliktu, tłumacząc się stanem swego zdrowia. Umarł 31 października 1607 roku w Ciążeniu. Jak zauważył Aleksander Stępkowski, trudno jednoznacznie wskazać datę przyjęcia przez niego święceń kapłańskich, wiadomo natomiast, że do godności biskupiej został podniesiony w 1577 roku, a dziesięć lat później został biskupem diecezji kamienieckiej, co raczej nie uchodziło za akt wyróżnienia. Następne nominacje wskazują jednak na rozwój jego kariery. W chwili śmierci kierował biskupstwem poznańskim i właśnie tam został pochowany. Życie Goślickiego pokazało, że łączył on role teoretyka i praktyka, polityka i filozofa oraz, co niezwykle istotne, kapłana. 


\section{Senat Rzeczpospolitej}

W Polsce w XVI wieku panował specyficzny ustrój ${ }^{8}$. Trójpodział władzy, czyli monarchia mixta9 ${ }^{9}$ zakładał, że nie ma jednego ośrodka władzy, ale że są trzy różne. Koncepcje trójpodziału władzy polscy autorzy opierali, podobnie jak i inni myśliciele renesansowi, przede wszystkim na Arystotelesie ${ }^{10}$, a w mniejszym stopniu na Platonie i Cyceronie. Istotne okazało się również nakładanie koncepcji wypracowanych przez starożytnych myślicieli na model trójpodziału władzy panujący w Rzeczpospolitej. Należy to odczytywać następująco: mamy króla, który jest ojcem wspólnoty ${ }^{11}$ (co w żadnym wypadku nie równa się władzy absolutnej), izbę poselską, czyli ogół obywateli posiadających prawa polityczne, oraz radę królewską, czyli senat. Monarchia mixta jest więc połączeniem demokracji, monarchii i arystokracji. Według Goślickiego w ustroju Rzeczpospolitej, w którym ani król, ani izba poselska nie mają pełnej władzy, szczególną rolę odgrywa prawo: „Przeto prawa znaczą u nich bardzo wiele, do których strzeżenia, zachowywania i utrzymana zobowiązuje się przysięgą religijną, tak dalece, iż uważają za hańbę i zbrodnie czynić coś wbrew prawu"12.

Senat, który znał i w którym zasiadał Goślicki, ukształtował się na przełomie XV i XVI wieku. Wyłonił się z rady królewskiej, organu który miał za zadanie doradzać królowi w rządach. $Z$ biegiem czasu rada zaczęła się jednak przeistaczać w samodzielne ciało, doradzające królowi. Początkowo w jego skład wchodzili przedstawiciele różnych środowisk i urzędów. Jednak z biegiem czasu senat stawał się instytucją coraz bardziej elitarną, złożoną jedynie z wyższych urzędników. W Rzeczpospolitej nie doszło natomiast do znanego w Europie Zachodniej procederu przekształcenia urzędu senatorskiego w przywilej dziedziczny zarezerwowany dla garstki magnatów. Senatorami zostawali prymas, arcybiskup gnieźnieński, część biskupów, wojewodowanie

\footnotetext{
${ }^{8}$ Więcej w: J. Ekes, Trójpodział władzy i zgoda wszystkich. Naczelne zasady „ustroju mieszanego" w staropolskiej refleksji politycznej, Siedlce 2001.

${ }_{9}^{9}$ Dyskusyjne jest używanie tych terminów jako synonimów, jednak na potrzeby tego tekstu nie będę wprowadzał rozróżnienia, które wymagałoby dokładnego opisania i wyjaśnienia.

${ }^{10}$ Dokładnie o relacji między myślą Goślickiego a Arystotelesem pisał A. Stępkowski De optimo senatore $w$ świetle arystotelesowskiej Polityki, [w:] O senatorze doskonałym studia, dz. cyt.

${ }^{11}$ Szerzej na ten temat u K. Grzybowskiego, Teoria reprezentacji w Polsce epoki odrodzenia, Warszawa 1958.

${ }^{12}$ W. Goślicki, dz. cyt., s. 101.
} 
oraz kasztelanowie ${ }^{13}$. Łącznie liczył on do 147 osób w czasie, kiedy Goślicki pisał swoją pracę. Szczególną rolę w senacie odgrywał król będący jego „głową i fundamentem"14. Wszystko, co dotyczy senatu, pośrednio dotyczy także króla, będącego również senatorem. Król miał wpływ na skład senatu, mogąc powoływać do niego „nowych ludzi” ${ }^{15}$. Kompetencją senatu było tworzenie prawa, refleksja nad konkretnymi ustawami i doradzenie królowi i tym samym pomoc w sprawowaniu władzy. Sucheni-Grabowska zwraca uwagę, że senatorowie służyli nie tyle samemu królowi, ile królestwu.

\section{Górski, Frycz, Orzechowski a senat}

Okres, w którym powstało De optimo senatore należy zaliczyć do złotego wieku staropolskiej myśli politycznej. Właśnie w drugiej połowie XVI wieku powstały najważniejsze dzieła, które stały się fundamentem dla formacji kulturowej sarmatyzmu.

Niezwykle istotne w próbie zrozumienia koncepcji Goślickiego jest wskazanie intelektualisty, który miał wpływ na uformowanie się jego koncepcji państwa. Niezaprzeczalnie najważniejszą postacią był Jakub Górski, nauczyciel Goślickiego w czasach jego nauki na Uniwersytecie Jagiellońskim. Trudno prześledzić dokładnie wpływ Górskiego na myśl autora De optimo senatore, chociaż niewątpliwie był niebagatelny ${ }^{16}$. Można natomiast dość łatwo wykazać wyraźne paralele między koncepcjami zawartymi w tekście Goślickiego a wydanym już po śmierci Górskiego traktacie Rada Państwa ${ }^{17}$. W obu tekstach przedstawiono konkretną wizję republikanizmu, pod pewnymi względami inną niż w przypadku innych autorów tej epoki. U obu autorów, na co zwraca uwagę Włodzimierz Bernacki w Myśli politycznej I Rzeczpospolitej, czytelnik znajdzie gloryfikację senatu. Obydwaj jednoznacznie opowiadają

${ }^{13}$ A. Sucheni-Grabowska, Ksztattowanie się koncepcji Senatu w XVI wieku, [w:] Senat w Polsce. Dzieje i teraźniejszość. Sesja naukowa 25 i 26 maja 1993, red. K. Matwijowski, J. Pietrzak, Warszawa 1993, s. 36.

${ }^{14}$ K. Grzybowski, dz. cyt., s. 92.

${ }^{15}$ A. Stępkowski, Senat doby jagiellońskiej, [w:] O senatorze doskonałym studia, dz. cyt., s. 87.

${ }^{16}$ Wskazuje na to chociażby A. Stępkowski w Wawrzyniec Grzymała Goślicki przyczynek do biografii, [w:] O senatorze doskonałym studia, dz. cyt., s. 11.

${ }^{17}$ J. Górski, Rada państwa, Kraków 1892. 
się po stronie systemu arystokratycznego, rady mędrców predystynowanych dzięki swoim umiejętnościom do rządzenia.

W swoim tekście będącym, jak zauważa Morawski, autorskim tłumaczeniem broszury renesansowego myśliciela Cerioliego ${ }^{18}$, Jakub Górski szczególnie uwypukla istotną rolę, jaką odgrywa rada państwa, czyli organ mający na celu piastowanie pieczy nad wszystkimi dziedzinami polityki królewskiej (czyli de facto senat) ${ }^{19}$. Oto jak pisał na wstępie swojego traktatu: „Rada państwa albo raczej królewska jest zebranie osób mądrych, z wielu obranych, których by król i pan używał we wszystkich potrzebach Rzeczypospolitej czasu pokoju i wojny" ${ }^{20}$. Członkowie rady winni, zdaniem Górskiego ${ }^{21}$, odznaczać się szeroką wiedzą historyczną, filozoficzną i polityczną 22 . To właśnie na nich spoczywa odpowiedzialność za kształt państwa i to właśnie oni odgrywają kluczową rolę w rządzeniu państwem ${ }^{23}$. Podobnie jak w przypadku Goślickiego, należy zwrócić uwagę na kierowanie się maksymalizmem etycznym podczas wyboru członków rady rządzącej. Podobnie jak jego uczeń, zwraca uwagę na panującą między ludźmi naturalną nierówność, stąd też i wybór członka rady powinien być podyktowany względami na konkretne cechy, takie jak: „dowcip przyrodzenia, znajomość polityki, języków obcych i historii oraz realizm" ${ }^{24}$. Nie ma co jednak ukrywać, że w stosunku do swego ucznia Górskiemu brakuje wyczucia filozoficznego, a jego dzieło jest w większym stopniu traktatem politycznym niż filozoficznym. W zupełnie innym duchu utrzymany był historyczny traktat Jana Zamoyskiego De senatu romano libri $I I^{25}$. Pracę tę można jednak odczytywać jako pewnego rodzaju „postulat”, jak powinien wyglądać senat. Jeszcze innego rodzaju tekstem były cieszące się złą

${ }^{18}$ Dzieło $O$ radzie $i$ doradcach Ceriola jest dzisiaj już praktycznie nieznane. Wydane w 1554 roku, cieszyło się dużą popularnością w drugiej połowie XVI wieku. Wiktor Czerniak w przedmowie do wydania Górskiego z 1882 roku wskazuje, że z oryginalnego traktatu zostało bardzo mało i że w większości mamy do czynienia z polską interpretacją dzieła Włocha, a nie jego tłumaczeniem.

${ }^{19}$ W. Bernacki, Myśl polityczna I Rzeczpospolitej, Kraków 2010, s. 117.

${ }^{20}$ J. Górski, dz. cyt., s. 9.

${ }^{21}$ Wśród intelektualnego środowiska należy na pewno wymienić również Łukasza Górnickiego, który jako pierwszy na większą skalę dokonał recepcji myśli platońskiej w Polsce.

${ }^{22}$ J. Górski, dz. cyt., s. 10.

${ }^{23}$ W. Bernacki, dz. cyt., s. 129.

${ }^{24}$ J. Górski, dz. cyt., s. 30-39.

${ }^{25}$ M. Kuryłowicz, W. Witkowski, Rozprawa Jana Zamoyskiego o senacie rzymskim, Lublin 1997. 
sławą Rady Kallimacha ${ }^{26}$, w których senat miał być jednym z narzędzi władzy króla-tyrana.

Inaczej do sprawy podszedł autor jednego z największego z traktatów z zakresu filozofii polityki staropolskiej Andrzej Frycz-Modrzewski. W wielkim projekcie modernizacji przedstawionej przez Modrzewskiego autor zaskakująco mało miejsca poświęcił senatowi. W dziele O poprawie Rzeczpospolitej zadedykował mu jedynie kilka uwag. Źródło idei senatu, czyli rady mędrców doradzających królowi wywodzi Modrzewski z tradycji biblijnej, wskazując na decyzję Mojżesza o podzieleniu się władzą ${ }^{27}$.

Poza refleksją nad genologią senatu Frycz-Modrzewski nie przedstawia żadnej dogłębnej refleksji. Jego stanowisko w kwestii senatu nie wykracza poza koncepcje przedstawione przez Górskiego:

Przed wszystkim zaś starać się należy, by stan senatorski był jak najlepiej dobrany, bo on jest po królu najwyższy, w każdej rzeczpospolitej. U nas składa się on z wszelkiego prawie rodzaju urzędników i duchownych i świeckich. Dlatego musi król z największą starannością poczynać sobie, gdy wybiera ludzi na urzędników, z których przyjęto składać senat, to znaczy najwyższą radę Rzeczpospolitej, stróża dobra publicznego i godności - tego, który króla i władzę zachęca do rzeczy pięknych i uczciwych, a odwodzi od szpetnych i nieuczciwych, który miarkuje jego przewrotne namiętności. Bez tego to senatu rady, zdania, powagi nie godzi się poczynać niczego w rzeczpospolitej ani poza nią. ${ }^{28}$

Chociaż fragment jest krótki, jednak obfity w treści. Wystarczająco wyraźnie jest wyrażony w nim zarówno status senatu, jak i jego zadanie. Na kształt senatu król ma ograniczony wpływ, jego skład regulują obecne w Rzeczpospolitej prawa nakazujące wybierać senatorów spośród wysokich urzędników świeckich i duchownych. Król może wpływać na skład senatu poprzez wybór ludzi do pełnienia określonych funkcji.

Znacznie bardziej interesujący jest sposób, w jaki Frycz interpretuje zadania stojące przed senatem. Ma być on stróżem dobra publicznego i godności - czyli prawa. Wyznacza tym samym ramy, w których porusza się władca.

Senator jest więc kimś w rodzaju mędrca czy też nauczyciela, który ma za zadanie wskazywać słuszną drogę władcy. Fakt, że ma zachęcać do rzeczy „pięknych i uczciwych” może wskazywać na trop myśli platońskiej i sugero-

\footnotetext{
${ }^{26}$ K. Baczkowski, Rady Kalimacha, Kraków 1989.

${ }^{27}$ A. Frycz-Modrzewski, O poprawie Rzeczpospolitej, Warszawa 1953, s. 139.

${ }^{28}$ Tamże, s. 142.
} 
wać, że senatorowie są tymi, którzy poznali prawdę. Taka interpretacja nie jest jednak wystarczająco uzasadniona, Frycz nie podaje w swoim tekście sugestii, że senatorowie są podobni filozofom, którzy za sprawą vita contemplativa pojęli istotę rzeczy. W jego interpretacji wydają się po prostu „mądrymi ludźmi” czy raczej „specjalistami”, strażnikami praw.

Senat u Modrzewskiego, tak jak w politycznej rzeczywistości I Rzeczpospolitej, miał zajmować miejsce pomiędzy dwoma dominującymi ośrodkami władzy. Król był strażnikiem praw i ich autorem i wydawało się, że jego władza jest szeroka, jednak każdy z jego projektów mieli zaakceptować reprezentanci szlachty, którzy posiadali ostateczne prawo akceptacji lub odrzucenia danego projektu ${ }^{29}$.

Chociaż Frycz powierza w ręce senatu istotne kompetencje wpływania na władzę, jednak już w kolejnym punkcie wydaje się osłabiać jego znaczenie. Opowiada się bowiem za koniecznością powstania rady królewskiej, która miałaby ciągle doradzać królowi. W przeciwieństwie do senatu, który miałby zbierać się tylko w sprawach najważniejszych. Znamienne jest, że Frycz nie precyzuje, czy Rada składałby się z senatorów, czy też król powoływałby ją z zaufanych ludzi. Stosuje zapis: „godzi się, aby król miał także kilku ludzi zaufanych, którzy by od jego boku nie odstępowali". Wydaje się zatem, że raczej nie chodzi o senatorów. Jeżeli tak, to rola senatu u Frycza zostaje zmarginalizowana do grupy mędrców, którzy nie mają faktycznego wpływu na kształt Rzeczpospolitej, przegrywają z żywiołem szlacheckim oraz królem i jego doradcami.

Podobnie mało miejsca kwestii senatu w państwie poświęcił Stanisław Orzechowski. Stosowne uwagi zamieścił w dwóch tekstach: Mowie żałobnej, jaka Stanisław Orzechowski z Rusi wygłosił do szlachty polskiej na pogrzebie Zygmunta Jagiellończyka. Króla polskiego oraz Mowie do szlachty polskiej przeciw prawom i ustawom Królestwa Polskiego uporządkowanym przez Jakuba Górskiego.

Dla Orzechowskiego senat w państwie jest pewnego rodzaju wentylem, dzięki któremu z jednej strony państwo nie popadnie w sidła tyranii, z drugiej - nie wpadnie w odmęty anarchii. Senat jest rodzajem papierka lakmusowego. Jak pisze: „I nie wiem, czy jest jakaś inna oznaka dobrego króla aniżeli jego senat”, senat jest bowiem "narzędziem dobrego rządzenia państwem”. Orzechowski zdaje się dogłębniej niż Frycz pojmować relację senat-król. Władca jest przecież jednym $\mathrm{z}$ senatorów i nie można oddzielić go od całego

29 Tamże, s. 140. 
zgromadzenia. „Jeżeli senat jest nic niewart, jeżeli jest niesprawiedliwy, rozpustny, chciwy i zbrodniczy, zaraz wiadomo, że i król jest do niego podobny"30. Senat warunkuje zachowanie władcy, ten bowiem ogłasza jedynie to, co przez senat zostało uchwalone ${ }^{31}$. Broni więc senat praw, wolności i ustroju państwa.

U Orzechowskiego senat wyraźnie odgrywa rolę dominującą względem króla. Zarazem jednak izba wyższa miała odróżniać się od izby poselskiej. Senator obdarzony większą wiedzą, doświadczeniem i erudycją mógł sprawniej rozeznać się w sprawach państwowych. Wizję tego, jakimi cnotami powinien odznaczać się senator, czerpał Orzechowski z klasycznych wzorców znanych między innymi z pism Cycerona. Dobry senator powinien wyróżniać się „dobrocią, mądrością, wymową i bogactwem ${ }^{32}$ ". Orzechowski nie zgłębia jednak tego zagadnienia i ogranicza się, podobnie jak Frycz-Modrzewski, do powołania się na pewien przyjęty już wzorzec.

\section{Filozof u władzy}

Na tym tle wyraźnie widać, jak stanowisko Goślickiego różni się od innych popularnych przekonań. Szczególnie że w stosunku do pozostałych autorów podjął się pogłębionej refleksji nad tym, jaki powinien być dobry senator.

Goślicki w De optimo senatore zajął stanowisko głoszące, że chociaż w Rzeczpospolitej formalnie panuje trójpodział władzy, jednak władzę faktyczną powinien mieć jeden z jej członów - senat. Oznacza to, że stał w opozycji zarówno do przedstawicieli demokracji, jak i regalistów, a jego koncepcja miała być polską recepcją części myśli Platona. Dlatego interpretować dzieło Goślickiego trzeba dwutorowo, z jednej strony poprzez pryzmat Platona, z drugiej poprzez system polityczny Rzeczypospolitej.

Oto jak Wawrzyniec Goślicki przedstawiał ustrój swojego państwa:

\footnotetext{
${ }^{30}$ S. Orzechowski, Mowa żałobna, jaka Stanisław Orzechowski z Rusi wygłosił do szlachty polskiej na pogrzebie Zygmunta Jagiellończyka, Króla polskiego, [w:] tenże, Wybór pism, Kraków 1972, s. 44.

${ }^{31}$ Tamże, s. 59.

32 S. Orzechowski, Żywot i śmierć Jana Tarnowskiego, [w:] tenże, Wybór pism, Kraków 1972, s. 254.
} 
Królestwo polskie złożone jest z trzech stanów: z króla, arystokracji i narodu. Nazwą narodu jednak obejmowani są tylko sami rycerze, czyli szlachta. Jest zaś w ich państwie wielka zależność stanów od siebie, bo król sam bez ich zgody i rady nie może zawyrokować w najważniejszych sprawach państwa - senat zaś podobnie nic nie może bez króla i szlachty ${ }^{33}$.

I nieco dalej:

Senat u nich przedstawia ustrój arystokratyczny, który (jak już powiedziałem) posiada bardzo wielką powagę i składa się z mężów wybranych spośród najmądrzejszych i najbardziej wysoko urodzonych, oni radzą z Królem o dobrym kierowaniu państwem i są tacy jak u Persów byli homotymi ${ }^{34}$.

Kilka stron wcześniej Goślicki wskazuje, jakie jego zdaniem państwo w historii świata było najbliższe ideałowi platońskiemu. Wymienia między innymi Spartę, ale i monarchię rzymską ${ }^{35}$. Właśnie w czasie jej panowania bowiem widział jedyny okres w historii Rzymu, kiedy zachowana była równowaga miedzy królem, ludem i senatorami. Podkreśla również, że i polski system republikański jest przykładem realizacji ideału platońskiego ${ }^{36}$. Goślicki nie chce zatem zmieniać systemu Rzeczypospolitej, uważa go bowiem za najlepszy z możliwych, swój projekt sparowania władzy przez filozofów chce wpisać w istniejący już ład.

Goślicki właśnie w senacie widział zgromadzenie filozofów, którzy mają rządzić państwem i już na wstępie nie krył się z tym, że bezpośrednią inspiracją dla niego były pisma Platona i Cycerona.

W tej książce zebrane to wszystko, co tylko szkoła Platona, przybytki państwowe, mądrość obywatelska, praktyka życia politycznego oraz skarbce historii i doświadczenia mogły powiedzieć o doskonałym senatorze ${ }^{37}$.

\footnotetext{
${ }^{33}$ W. Goślicki, dz. cyt., s. 99-101.

${ }^{34}$ Tamże, s. 101.

35 Tamże, s. 97.

${ }^{36}$ Goślicki, podobnie jak inni pisarze polityczni tamtego okresu wychwalający system Rzeczypospolitej, nie głosi, że polski system jest doskonały. Głosi, że w jego założeniach tkwi potencjał sprawiający, że jest on najbliższy ideałowi. Kiedy więc Goślicki pisze o Rzeczypospolitej jako państwie na wzór platoński, ma na myśli tkwiący w nim potencjał.

${ }^{37}$ W. Goślicki, dz. cyt., s. 13.
} 


\section{A nieco dalej:}

Ponieważ zaś Platon poucza nas, że państwo dopiero wtedy będzie szczęśliwe, kiedy rządy należeć będą albo do filozofów, albo też do tych, którzy oddadzą się zupełnie studiom mądrości, dlatego też zacznę swój wykład o doskonałym senatorze od mądrego męża i od tej mądrości państwowej i obywatelskiej ${ }^{38}$.

A zatem Goślicki łączy swoje uznanie do senatu z platońską tradycją nakazującą powierzyć władzę w państwie filozofom ${ }^{39}$. Nawet wśród wielu, szczególnie ówczesnych filozofów, takie postawienie sprawy rodziło kontrowersje. Uważano, że hazardem jest powierzanie sterów państwa filozofom, którzy ze swojej natury odznaczają się refleksyjnym sposobem życia, każącym dokładnie badać każdą kwestię, bagatelizującym tym samym tak istotny w uprawianiu polityki refleks.

Dlaczego właśnie filozof jest w najwyższym stopniu predestynowany do rządzenia państwem? Decydującą rolę odgrywa tutaj tradycja platońska, na którą powoływał się sam autor. Nie chciał on jednak poprzestać tylko na powoływaniu się na antyczną tradycję. Filozofowie bowiem wiedzą, jakie życie prowadzi do szczęścia. To właśnie oni określili warunki składające się na doskonałe szczęście człowieka: naturę, obyczaje, rozum, i najlepiej są w stanie przy ich pomocy działać. Pod warunkiem, że kierują się w życiu zasadą aktywności, a nie potrzebą kompletacji i czczą retoryką. Kluczowe jest bowiem posługiwanie się w życiu rozumem, który jest najlepszą cząstką w duszy człowieka ${ }^{40}$. Doskonały senator jest osobą, która zgłębia pierwszą i najbardziej podstawową naukę:

${ }^{38}$ Tamże, s. 17.

${ }^{39}$ Wydaje się, że ten fragment leży bezpośrednio u podstaw koncepcji Goślickiego. „Jak długo - zacząłem - albo miłośnicy mądrości nie będą mieli w państwach władzy królewskiej, albo ci dzisiaj tak zwani królowie i władcy nie zaczną się w mądrości kochać uczciwie i należycie, i pokąd to się w jedno nie zleje - wpływ polityczny i umiłowanie mądrości - a tym licznym naturom, które dziś idą osobno, wyłącznie tylko jednym albo wyłącznie drugim torem, drogi się nie odetnie, tak długo nie ma sposobu, żeby zło ustało, kochany Glaukonie, nie ma ratunku dla państw, a uważam, że i dla rodu ludzkiego. Ani mowy o tym nie ma, żeby taki ustrój prędzej w granicach możliwości dojrzał i światło słońca zobaczył, ustrój, którymś teraz w myśli przeszli. To jest to, co mnie od dawna napawa wahaniem, czy to mówić, bo to będzie brzmiało bardzo opacznie i niewiarygodnie. Tak trudno jest dojrzeć, że na innej drodze nie znajdzie się szczęścia ani dla jednostki, ani dla państwa (Państwo C474 c-e).

${ }^{40}$ W. Goślicki, dz. cyt., s. 151. 
Nie ma niczego na tym świecie, czy to myślałeś, czy to robiłeś, czy to w państwie, na rynku, czy w sądzie, czy to było duże, czy małe, co by nie pochodziło od filozofii, rodzicielki wszystkich rad, czynności i zmysłów, jeśli ją sobie weźmiesz do naśladowania we wszystkich słowach i czynach, wtedy z pewnością to, co będziesz mówił czy robił, będzie roztropne, boskie i ze wszech miar doskonałe ${ }^{41}$.

Ktoś nieprzychylny Goślickiemu mógłby mu zarzucić, że ma na myśli po prostu wiedzę operacyjną. Ale na początku tego samego akapitu definiuje on filozofię również jako naukę o metafizyce. Nie jest więc dla niego filozofia po prostu uporządkowaną wiedzą o życiu, ale jak najbardziej nauką o ideach, i właśnie człowiek, który bada je, powinien kierować państwem.

Goślicki jest świadomy tego problemu. Będąc dzieckiem swoich czasów, przedstawicielem polskiej tradycji wychowania, podobnie jak inni filozofowie Rzeczypospolitej patrzy na filozofię zupełnie innymi niż antyczni myśliciele oczami. Dopasowuje myśl Platona do realiów i dokonuje podziału na trzy różne rodzaje życia.

Zdaniem filozofów, istnieje trojaki sposób życia. Pierwszy polega na działaniu, drugi na rozmyślaniu, a trzeci na oddawaniu się rozkoszom. Ten ostatni, niewola żądzy i rozkoszy, właściwy jest zwierzętom i najniższym ludziom, ten co polega na działaniu, jeśliby był pozbawiony filozofii i cnoty, jest głupi i ma wielkie wady, jak również i ten który ukrywa się w dociekaniu prawdy, jeśli jest odłączony od działania, jest zupełnie bezużyteczny ${ }^{42}$.

Podział ten nie był niczym nowym, znano go z pism klasycznych autorów. Używano go powszechnie w Rzeczpospolitej w trakcie edukowania młodych ludzi ${ }^{43}$. Jednak o ile Platon skłaniał się ku przyjęciu za najlepszy model vita contemplativa, a nieufnie podchodził do vita activa, o tyle w Rzeczpospolitej, w której starano się iść za myślą Arystotelesa ${ }^{44}$, ten drugi model był uznawany za doskonalszy. W szczególności u autora Państwa łatwo było wskazać,

${ }^{41}$ Tamże, s. 153.

${ }^{42}$ Tamże, s. 53.

${ }^{43}$ D. Żołądź-Strzelczyk, Ideały edukacyjne doby staropolskiej. Stanowe modele i potrzeby edukacyjne szesnastego i siedemnastego wieku, Warszawa 1990, s. 9.

${ }^{44}$ Arystoteles, Polityka, VII, 1, $\$ 3,5$. Fragment u Stagiryty nie jest do końca jednoznaczny. Filozof pisze w nim, że życie aktywne może się również realizować w sferze politycznej. W staropolskiej recepcji uważano, że życie aktywne oznacza właśnie realizację w sferze polityki. 
jaką drogą powinien podążać filozof i że najlepszą jest właśnie ta, w której w centrum jest kontemplacja idei Dobra i Piękna, a siłą rzeczy oznacza to zamknięcie na inne obszary rzeczywistości. Taka interpretacja w równym stopniu jest popularna, co upraszczająca. Zasadne jest pytanie, na ile Goślicki dokonał zmian Platona przy pomocy Arystotelesa, a na ile wnikliwie wczytuje się w Platona. Przecież to właśnie u Platona filozofowie muszą być wyrwani ze świata idei, aby rządzić państwem, a u Arystotelesa ideałem jest kontemplacja. Bez względu na to, jaką interpretację przyjmiemy, Goślicki wyraźnie odchodzi od takiej wizji odciętego od realnego świata myśliciela i zupełnie inaczej widzi filozofa u steru nawy państwowej.

Filozofia jako dążenie do kontemplacji idei być może jest istotna, ale w przypadku polityków jest rzeczą zgubną. Z pozoru mogłoby się wydawać, że będzie to dla Goślickiego dylematem trudnym do rozstrzygnięcia. Trzeba przecież w jakiś sposób połączyć senatora jako filozofia, przy jednoczesnym nieakceptowaniu sytuacji, w której za decyzje w państwie odpowiedzialny jest człowiek pokroju Diogenesa z Synopy. Aby rozwikłać tę aporię Goślicki podszedł do sprawy metodycznie. Na początek zaznaczył, jacy filozofie nie nadają się na rządzących:

Aby ogólnie powiedzieć, uważam, iż są dwa rodzaje filozofów nie nadających się do rządzenia państwami. Do pierwszego z nich należą tacy, co zaledwie wierzchem warg skosztowali filozofii i jej wskazówkami nie ugasili w sobie płomieni i pragnienia żądz i wad. Stąd też tacy prowadzą życie niezgodne z filozofią i cnotą, filozofia bowiem, która zwykła zarazem czynić ludzi uczonymi i dobrymi, nie zapuściła w nich głębokich korzeni: uczonymi przez mądrość i roztropność, dobrymi zaś przez sprawiedliwość, umiarkowanie i męstwo ${ }^{45}$.

A zatem niemożliwe jest, aby władzę w państwie piastowali ludzie niedojrzali. Filozofia musi odcisnąć na nich swoje piętno. Jak pisze nieco dalej, nie może to jednak być nazbyt głębokie zranienie:

Drugi rodzaj filozofów jest zupełnie inny niż tamtych, ci oddali się filozofii już od samej kołyski i w niej się zestarzeli, przylegając do niej, jak do skał syrenich. Ich sposób rozmyślania i filozofowania, ponieważ nie dotyczy korzyści ludzi i spraw państwowych, nie jest pożyteczny dla państwa i chociaż są oni rozumni

${ }^{45}$ W. Goślicki, dz. cyt., s. 157. 
i uczeni, to jednak ponieważ żyją tylko w kryjówkach filozofii i nie dotykają spraw publicznych, zwykli nie nadawać się do kierowania ${ }^{46}$.

Tym samym Goślicki rozwiązuje dylemat związany z najczęstszym z zarzutów kierowanych pod adresem koncepcji Platona. Zaraz też udziela odpowiedzi na pytanie, jaki rodzaj filozofów najlepiej nadaje się na senatorów.

Należy tedy sądzić, iż pośredni rodzaj filozofów nadaje się do rządzenia państwami. Oni bowiem zwykli szukać w tych studiach filozofii niczego innego, jak tylko wskazówek potrzebnych do szczęśliwego życia i kierowania państwami. Zachęcam tedy mojego senatora do tego rodzaju studiów filozofii, otrzyma bowiem z niej nie tylko wiedzę o szczęściu ludzi, ale także o rządzeniu państwem $^{47}$.

Wydaje się zatem, że autor De optimo senatore dokonuje interpretacji myśli Platońskiej przy użyciu narzędzia znanego z filozofii Arystotelesa - złotego środka ${ }^{48}$. Goślicki projektował, że właśnie tacy ludzie, kierujący się zasadami vita activa, okażą się najlepszymi senatorami. Będą moderatorami Rzeczypospolitej, dzięki którym zostanie zrealizowany ideał platońskiego państwa ${ }^{49}$. Wskazuje również, które koncepcje filozoficzne są szkodliwe. Wśród nich za wątpliwy uznaje stoicyzm, przedstawiciele tej szkoły zasklepiają się bowiem w sobie i uważają innych za głupców ${ }^{50}$, a najlepszym, jego zdaniem, rodzajem filozofów są perypatetycy. Ich działania będą kierowane ku obywatelom i będą oni żyli tym, czym żyją inni ludzie.

Ostatecznie senator-filozof miał być człowiekiem odznaczającym się naturą umiarkowaną, sprawiedliwą i cnotliwą. Nie było decydujące jego pochodzenie, pozostawał także obojętny na pokusę łączenia bogactwa materialnego ze sprawowaniem funkcji kierowniczych w państwie. Jego zdaniem, jeśli taki stan rzeczy by zaszedł, prowadziłoby to do wypaczania ustroju w stronę groźnej oligarchii ${ }^{51}$. Nie oznacza to jednak, że staropolski teoretyk odrzuca cenzus urodzenia przyszłego senatora. Goślicki nie dopuszczał do współudziału we władzy chłopów i mieszczan. Kiedy piszę, że nie było dla niego decydujące

\footnotetext{
${ }^{46}$ Tamże, s. 157-159.

47 Tamże, s. 161.

${ }^{48}$ Albo jak zaznaczyłem w tekście, po prostu bardzo uważnie odczytał Platona.

${ }^{49}$ Więcej w: D. Pietrzyk-Reeves, Ład Rzeczpospolitej, Kraków 2010, s. 51 oraz J. Mańkowski, Moderator i filozof, [w:] O senatorze doskonałym, dz. cyt., s. 93-116.

${ }^{50}$ W. Goślicki, dz. cyt., s. 191.

${ }^{51}$ Tamże, s. 129.
} 
pochodzenie, rozumiem, że nie upierał się, aby senatorem-filozofem musiał zostać z konieczności arystokrata - mógł nim być każdy szlachcic. Na poparcie tej tezy przedstawia popularne w tym czasie twierdzenie, że już w samym słowie „szlachcic” zawiera się informacja, że jest on człowiekiem cnotliwym. A cnota ta wynika w równym stopniu $\mathrm{z}$ niego samego, jaki $\mathrm{z}$ dziedzictwa jego przodków ${ }^{52}$.

Decydującą rolę w wywodzie Goślickiego odgrywało to, jakim człowiekiem był pretendent do wysokich urzędów i czy odznaczał się pożądanymi cechami charakteru. Pełen kodeks cnót i wymagań, jakie są mu stawiane, przedstawił Goślicki w drugiej księdze swojego traktatu. Ponadto do odpowiedzialnego zadania, jakim jest rządzenie państwem, kandydaci na wysokie urzędy powinni być wychowani od najmłodszych lat, tak aby lepiej móc je wypełniać. Wizja senatora zamieszczona w części drugiej dzieła jest w dużej mierze recepcją myśli cyceroniańskiej i okazuje się po prostu katalogiem cnót i cech, jakimi powinien legitymizować się senator doskonały. Nie ma potrzeby wnikać w szczegóły tej listy, jest ona taka sama jak w przypadku innych autorów zaliczanych do tradycji republikańskiej. Ważne jest, że doskonały senator podporządkowuje swoje życie rozumowi, tożsamemu z potrzebą nieustannego kierowania się nakazami filozofii.

O ile więc Frycz-Modrzewski de facto zmarginalizował rolę senatu, Orzechowski zaś przypisał mu funkcję dosyć niejednoznaczną, o tyle Goślicki jasno nakreślił powinności senatu. To właśnie izba wyższa ma wypełniać decydującą misję w państwie. Senatorowie mają panować nad dwoma żywiołami: królem, który dąży do władzy absolutnej, i sejmem, który pragnie wybić się samodzielność. Senatorom ma przysługiwać ostateczny głos i to oni powinni rozstrzygać, które decyzje są dobre, a które nie. Tym samym różni się w tym punkcie Goślicki od Orzechowskiego, który decydujący głos w podejmowaniu uchwał oddawał zgromadzeniu posłów.

\footnotetext{
${ }^{52}$ W. Goślicki, dz. cyt., s. 131. Warto jednak odnotować, że sprawa akcesu do stanu szlacheckiego dla Goślickiego jest zupełnie osobną kwestią. W czasie, kiedy Goślicki pisał swoje dzieło, stan szlachecki nie był zamknięty i dochodziło do nobilitowania mieszczan i chłopów. Dla Wawrzyńca Goślickiego taka rzecz była do zaakceptowania, o ile osoba dopuszczona do godności szlacheckiej żyła cnotliwe.
} 


\section{Podsumowanie}

Poglądy Goślickiego wyróżniają się na tle innych koncepcji filozoficznych staropolskiego dyskursu politycznego. Jego awangardowość, bo chyba właśnie to słowo najlepiej opisuje jego koncepcję, odznacza się nie tylko jednoznacznym opowiedzeniem się za dominującą rolą senatu, ale również nakreśleniem niezwykle pogłębionej analizy powinności senatora, w których chce widzieć filozofów opisanych przez Platona w Państwie.

Opowiedzenie się za senatem stawiało Goślickiego w opozycji do większości społeczeństwa posiadającego prawa wyborcze. Kiedy pisał on swój traktat, cały czas żywy był spór między zwolennikami ruchu egzekucji praw i dóbr, gdzie senat odbierany był jako przeciwnik demokracji i zarazem obrońca interesów magnaterii. Autor De optimo senatore odpowiadał się również za powstrzymaniem rodzących się właśnie tendencji do zwiększenia zakresu władzy królewskiej.

Znacznie ciekawszy od tego, kogo wskazuje Goślicki jako organ sprawujący władzę, jest jego wybór określonej tradycji filozoficznej. Autor zdecydował się postawić tezę, że konieczne jest, aby władzę w Rzeczpospolitej sprawowali filozofowie, czym bezpośrednio odwołał się do tradycji Państwa Platona, tj. koncepcji, która nie cieszyła się popularnością w zdominowanej przez poglądy Arystotelesa staropolskiej myśli filozoficznej.

\section{Bibliografia}

Arystoteles, Polityka, Warszawa 2006.

Bernacki W., Myśl polityczna I Rzeczpospolitej, Kraków 2010.

Barcz H., Polacy na studiach w Rzymie w epoce Odrodzenia 1440-1600, Kraków 1938. Goślicki W., O senatorze doskonałym, Kraków 2000.

Ekes J., Trójpodział władzy i zgoda wszystkich. Naczelne zasady "ustroju mieszanego" w staropolskiej refleksji politycznej, Siedlce 2001.

Frycz-Modrzewski A., O poprawie Rzeczpospolitej, Warszawa 1953, s. 139.

Górski J., Rada Pańska, Kraków 1892.

Grzybowskiego K., Teoria reprezentacji w Polsce epoki odrodzenia, Warszawa 1959.

Kuryłowicz M., Witkowski W., Rozprawa Jana Zamoyskiego o senacie rzymskim, Lublin 1997.

Orzechowski S., Wybór pism, Kraków 1972. 
Platon, Państwo, Kęty 2003.

Pietrzyk-Reeves D., Ład Rzeczpospolitej, Kraków 2010.

Sucheni-Grabowska A., Kształtowanie się koncepcji Senatu w XVI wieku, [w:] Senat w Polsce. Dzieje i teraźniejszość. Sesja naukowa 25 i 26 maja 1993, red. K. Matwijowski, J. Pietrzak, Warszawa 1993.

Stępkowski A. (red.), O senatorze doskonatym studia prace upamiętniające twórczość Wawrzyńca Goślickiego, Warszawa 2009.

Żołądź-Strzelczyk D., Ideały edukacyjne doby staropolskiej. Stanowe modele i potrzeby edukacyjne szesnastego i siedemnastego wieku, Warszawa 1990.

\section{Abstract \\ Philosophers' State. The Idea of Senate in De optimo Senatore by Wawrzyniec Goślicki}

The article presents a specific reception of the Platonic philosophy by Wawrzyniec Goślicki, one of the most important Polish thinkers of the Renaissance. This philosopher in his treatise De optimo senator argued that the commonwealth should be ruled by the senate made of philosophers. It was Platon's Republic that served as an inspiration for such a concept. The Polish thinker stated firmly that philosophers are predestined to guide the country and they are the only ones that are able to combine practice with a deep philosophical deliberation. The author's views had a chance to be tested in real life, because Goślicki himself was not only a well-educated philosopher but became an influential senator. The concepts presented by Goślicki, in which philosophers-senators should rule the state, were especially innovative in comparison to other concepts that arose at that time on the territory of the PolishLituanian Commonwealth. Therefore, in this article Goślicki's views are confronted with the visions of the role of senators presented in the writings of the two greatest Polish political writersof the time, i.e. Stanisław Orzechowski and Andrzej Frycz Modrzewski.

Key words: Goślicki, Plato, Aristotle, political philosophy, the role of philosophy, republicanism 